\title{
Pristupi proučavanju medija
}

\author{
Mirko PETRIĆ \\ Odjel za sociologiju, Sveučilište u Zadru \\ mpetric@unizd.hr
}

- Zrinjka Peruško (ur.). Uvod u medije. Zagreb: Naklada Jesenski i Turk, Hrvatsko sociološko društvo, 2011, 361 str.

Pojavu na hrvatskoj akademskoj sceni zbornika tekstova domaćih autora/ica o medijima, koji uz to aspirira na status udžbenika, načelno valja svakako pozdraviti. Javna percepcija važnosti uloge medija u društvenom životu, naime, neprestano raste, kao i pritisak zainteresirane studentske populacije na visokoškolske ustanove i studijske grupe koje nude poduku o različitim sadržajima povezanim s medijima. Poteškoća s kojom se neizostavno susreću svi koji predaju kolegije o takvim sadržajima jest nedostatak primjerene popratne stručne literature, osobito na početnoj razini studija, na kojoj se od polaznika/ca još ne očekuje suvereno vladanje različitim znanstvenim izvorima i mogućnost široke upotrebe literature na stranim jezicima.

Pokušaj priređivanja zbornika pod naslovom Uvod u medije, koji bi prilozima domaćih autora/ica ispunio sve teže održivu prazninu u području medijskog obrazovanja, osobito je hvalevrijedan i stoga što se - ne samo u ovom području - pokazalo da prijevodi priručnika nastalih u drugim sredinama nedovoljno dobro ispunjavaju namijenjenu im obrazovnu ulogu. Bez obzira na to koliko iscrpno obrađivali svoj predmet, takvi radovi jednostavno ne mogu odgovoriti na potrebe proizišle iz specifičnih povijesnih i institucionalnih konteksta pojedinih društava i intelektualnih tradicija. Posljedice njihova objavljivanja stoga su, vrlo često, dvojbene: s jedne strane, lokalna publika u nedovoljnoj mjeri prihvaća njihov sadržaj, što stvara poteškoće nakladnicima i čini ih vrlo opreznima pri donošenju odluka o objavljivanju čak i potencijalno isplativih naslova ove vrste. S druge strane, nije pretjerano ustvrditi da kad - silom prilika - pojedini takvi sadržaji i udžbenici uđu u širu upotrebu, na specifičan način pridonose intelektualnoj kolonizaciji čitateljstva i ukupnoga akademskog pogona u kojem se upotrebljavaju. ${ }^{1}$

${ }^{1}$ U području sociologije, za ilustraciju ovdje izrečenih tvrdnji nije potrebno ići dalje od glasovitoga »globalnog« udžbenika sociologije Anthonyja Giddensa (2007), čije se hrvatsko izdanje očekivalo sa znatno većim entuzijazmom nego što ga danas izaziva njegova konačna uporabna vrijednost u nastavi. Ta i slične knjige pokazuju da primjeri koji ilustriraju »aktualne probleme« vrlo brzo zastarijevaju, a također i to da globalno važne teme 
U području proučavanja medija, stanje je u ovom smislu čak teže nego u ostalim područjima. Naime, s obzirom na strelovit razvoj novih tehnologija i brzo prihvaćanje praksi zasnovanih na njima, još je vidljiviji raskorak između kontura nastajuće društvene zbilje i sposobnosti akademske zajednice za teorijsko promišljanje primjereno njihovoj kompleksnosti. Literatura u različitim poljima i disciplinama povezanim s proučavanjem medija, pogotovo kad je riječ o publikacijama knjižnog opsega, u velikoj mjeri je prijevodna, a radovi na različite medijske teme koje su u tranzicijskom razdoblju počeli proizvoditi domaći autori/ce vrlo često tek trebaju zadovoljiti drugdje uobičajene područne akademske standarde.

Ne usredotočujući se u ovom trenutku na kvalitetu ili tematske prioritete tih radova, u osvrtu pisanom za sociološki časopis zacijelo nije naodmet spomenuti da je u proteklih dvadeset godina postsocijalističke tranzicije, usporedno gledano, u području sociologije bilo znatno manje radova i istraživačkih inicijativa koje su se bavile medijskim temama nego u drugim područjima društvenih i humanističkih znanosti. Štoviše, nipošto ne bi bilo pretjerano ustvrditi da je upravo sociologija disciplina koja se u ovom kontekstu doživljavala kao manje produktivna i manje važna od drugih. ${ }^{2} \mathrm{U}$ javnoj percepciji pretekle su je srodne društvene discipline politologije, psihologije i pedagogije, kao i praktično usmjereni studiji novinarstva i komunikacija te na koncu različiti pokušaji teoretiziranja odnosa medija, kulture i društva na umjetničkim akademijama i u okviru interdisciplinarnih kulturnih studija.

Imajući sve ovo na umu, pojava zbornika s naslovom Uvod u medije u »Sociološkoj biblioteci« uglednog nakladnika, objavljena uz to u suradnji sa sociološkom strukovnom udrugom (HSD), unaprijed veseli ali, s druge strane, stvara možda i nerealno visok »obzor očekivanja«. Nakon dugogodišnje hibernacije, od nje bi se očekivalo da pokuša nadoknaditi propušteno i podigne akademske standarde u području, a možda i da se - nakon razdoblja prevlasti multidisciplinarno ili interdisciplinarno određenih »medijskih studija« - pokuša pridružiti aktualnim pokušajima korištenja prednosti specifično sociološkog pogleda na tematiku. ${ }^{3}$

viđene iz britanske perspektive ne moraju nužno pobuđivati interes u drugim sredinama. Nasuprot tome, trajan uspjeh lokalno kontekstualiziranih udžbenika s čvrstim uporištem u teoriji, poput Solarove Teorije književnosti (2005) ili Peterlićevih Osnova teorije filma (2001), od kojih je prvi trenutačno u svom dvadesetom (!) a drugi u četvrtom izdanju, ukazuje na prostor za pojavu i pretpostavljivo entuzijastičan prijem slično zamišljenih početnih sveučilišnih priručnika u području proučavanja odosa medija i društva.

${ }^{2}$ Pouzdane procjene o brojnosti, profilu i kvaliteti radova nastalih u području istraživanja medija u Hrvatskoj u tranzicijskom razdoblju bit će moguće tek nakon izrade anotirane bibliografije jedinica uključenih u skupni katalog Nacionalne i sveučilišne knjižnice. Valja, međutim, napomenuti da u stvaranju javne percepcije istaknutosti pojedinih disciplina u obradi nekog područja sudjeluju i medijski istupi osoba koje se povezuju s njima, brojnost i vidljivost znanstvenih i stručnih skupova u organizaciji strukovnih udruga te sudjelovanje praktičara/ki u privatno naručenim istraživanjima pojedinih segmenata područja.

${ }^{3} \mathrm{U}$ ovom smislu indikativni su, primjerice, naslovi zapaženih priručnika Michelea Soricea (2005, 2009), koji eksplicite ističu sociološku perspektivu, kao i Silverstoneov (2005) po- 
Međutim, već čitanje prve rečenice predgovora zborniku raspršuje sva neprimjerena očekivanja. Urednica Zrinjka Peruško u njoj čitateljstvo obavještava da je knjiga nastala »kao odgovor na potrebu za literaturom koja bi govorila o masovnim medijima i iz gledišta njihove pozicije i uloge u Hrvatskoj na kolegiju Uvod u medijske sustave na studiju novinarstva Fakulteta političkih znanosti u Zagrebu« (Peruško, 2011a: 7). Budući da je svrha tog kolegija pružiti »prvi cjelovit uvid u razumijevanje medija kao društvene, kulturne i političke institucije u medijskom sustavu« (Peruško, 2011a: 7), urednica smatra da i zbornik koji je osmislila može poslužiti kao prvi korak u tom pravcu.

Ciljevi i konstrukcija izdanja. Da bi se ostvarili zacrtani ciljevi - za koje će se pokazati da nisu jednostavni i da ih nije malen broj - urednica je od suradnika i suradnica zatražila da u svojim prilozima zborniku »obuhvate nastanak i razvoj medijske institucije ili prakse u Hrvatskoj i u svijetu, sadašnje stanje i perspektive razvoja« (Peruško, 2011a: 7). Još konkretnije, prema uredničkoj zamisli, »[p]oglavlja nastoje istovremeno sažeto prikazati stanje i znanstvenu raspravu o ključnim izazovima ili problemima određenog medija ili medijske prakse« (Peruško, 2011a: 7-8). Pritom je bio određen samo formalni okvir, odnosno konstrukcija poglavlja u kojoj se obvezno tražio sažetak, kratka definicija medija i medijske prakse o kojoj se govori te popis literature preporučene za daljnje istraživanje. U sadržajnom smislu, obaviješteni smo u predgovoru zborniku, »odgovornost za pojedina poglavlja preuzeli [su] autori koji su stručnjaci za temu o kojoj pišu, a velik broj njih o tome i predaje na Sveučilištu u Zagrebu« (Peruško, 2011a: 7).

Nakon uvodnog poglavlja, koje je pod naslovom »Što su mediji?« napisala urednica Zrinjka Peruško, slijede tako prilozi posvećeni mediju knjige (Mihaela Majcen Marinić), novinama (Gordana Vilović), filmskom mediju (Nikica Gilić), radiju (Marina Mučalo), televiziji (Tena Perišin), povijesti stripa (Sanjin Dragojević i Hrvoje Frančeski), novim medijima i novinarstvu na internetu (Nenad Pre$\log$ ) te novinskim agencijama (Fjodor Polojac). Zbornik zaključuju poglavlja o »najvažnij[im] profesionaln[im] praks[ama] koje su povezane s medijima kao kulturnom industrijom « (Peruško, 2011a: 8), odnosno prilozi o oglašavanju (Ante Gavranović), istraživanju publika (Antonija Čuvalo), autorskim pravima u medijskim industrijama (Kristina Delfin Kanceljak) te odnosima s javnošću (Božo Skoko).

Nažalost, i prije no što se pomno iščita opsežna građa prikupljena u zborni$\mathrm{ku}$, temeljno uredničko postavljanje problematike najavljuje stanovite poteškoće konceptualne i praktične naravi. Isto vrijedi i za deklarirano odustajanje od uredničkih intervencija u sadržaj pojedinačnih poglavlja, što je osobito zabrinjavajuće

kušaj inauguriranja novoga sociološkog okvira za proučavanje medija. U duhu povezivanja djelovanja medija i društava na koje se odnose (Balle, 2003), u prošlogodišnjem pozivu za prilaganje priopćenja konferenciji Istraživačke mreže za sociologiju komunikacija i istraživanje medija Europskoga sociološkog društva, članstvo se - između ostaloga - potiče na »formuliranje istraživanja u odnosu prema sociološkoj teoriji i pojmovima«, te »empirijski rad koji se bavi usporednim temama i glavnim preokupacijama europske sociologije« (ESA, 2010). 
s obzirom na šarolik, u nekim aspektima posve neočekivan i nestandardan odabir suradnika i suradnica. ${ }^{4}$

Konceptualne poteškoće. Kad je riječ o konceptualnim poteškoćama, one se odnose ponajprije na opseg pokrivanja tematike i žanrovsku nejasnoću pri odabiru pristupa. Očekivani karakter razmatranja naznačen u predgovoru izdanju urednički je vrlo ambiciozno postavljen, baš kao i opseg građe koju se u izdanju smjeralo obraditi. S obzirom na to, neupitno je da bi prikladan odgovor na zahtjeve postavljene pred autore i autorice pojedinačnih poglavlja - uz općenito visoku znanstvenu razinu - zahtijevao i osobit dar sinteze elemenata različitih pristupa medijima. Dosadašnja iskustva, međutim, pokazuju da je moguće prirediti vrlo uspješne udžbenike u »žanrovski« jasno određenim područjima poput medijske pismenosti, povijesti medija ili medijske teorije, ${ }^{5}$ a da znatno teže uspijevaju pokušaji sinteze različitih elemenata u međuvremenu tematski i disciplinarno vrlo razvedenog područja, osobito kad pokušavaju uključiti raspravu o društvenim i kulturnim promjenama povezanim sa širenjem novih tehnologija i upotrebom digitalnih interaktivnih medija. ${ }^{6}$

Doduše, valja napomenuti da u ovom zborniku takvih pokušaja nema, niti na razini usputnog spominjanja retoričke naravi (lip service), u razvijenijim sredinama uobičajenog već i u novinskom diskursu. Iz rasprave posve izostaju pojmovi poput »individualizacije«, »globalizacije«, »refleksivne modernizacije«, »umreženog društva«, pa i svenazočnih »društvenih medija«, a nekmoli pokušaji opsežnije rasprave o elementima nastajuće »medijatizacije« društvenog i kulturnog iskustva (Silverstone, 2005).

To znači da su unaprijed izbjegnute sve mogućnosti zapletanja u mreže društvene i teorijske »nove nepreglednosti«, ali s druge strane podsjeća na to da je cijeli zbornik zasnovan na temeljnom shvaćanju pojma i na raspravama o medijima koje prethode aktualnom stanju. Konkretno, urednica je - ako je suditi prema pred-

\footnotetext{
${ }^{4} \mathrm{Uz}$ suradnike i suradnice posvećene isključivo znanstvenom radu, te one koji u svom djelovanju spajaju profesionalnu praksu i akademsku poduku, na prilaganje poglavlja zborniku u ovom su slučaju pozvane i osobe koje su sa svijetom medija povezane samo dnevnom profesionalnom praksom. Uz dužno poštovanje stručnosti tih suradnika i suradnica, valja reći da je u njihovu slučaju unaprijed teško očekivati uspješno ispunjenje postavljenih ciljeva, koji su eminentno znanstvene naravi, a po svojoj zahtjevnosti također pretpostavljaju dugogodišnji rad u znanosti.

${ }^{5}$ U ovom smislu, kao uzor u području medijske pismenosti može poslužiti udžbenik Stanleya J. Barana (2002), u području povijesti medija priručnik Briggsa i Burkea (2005), a u području medijske teorije Arjena Muldera (2004).

${ }^{6}$ Kao primjer u ovom slučaju može poslužiti udžbenik Norberta Bolza (2007), pisan kao svojevrsna esejistička potpora studiranju medijske znanosti na diplomskoj razini »bolonjskog« studija. Slično vrijedi i za priručnik Francisa Ballea (2004), po temeljnom profilu inače sličan ovdje recenziranom udžbeniku. Razvedenost i trusnost recentnih odnosa medija i društva, koje također pokušava obuhvatiti u svom prikazu, čine ga manje pouzdanim i preglednim od disciplinarno jasno određenih priručnika na slične teme ranije objavljenih u PUF-ovoj seriji Que sais-je?, poput primjerice onih o komunikacijskim (Lazar, 1992) ili informacijskim (Le Coadic, 1994) znanostima.
} 
govoru i uvodnom poglavlju u zborniku - u svoj uređivački posao ušla sa stajališta koje središnjim predmetom rasprave smatra »masovne medije«, a disciplinom koja ih proučava »masovne komunikacije«, koje u tekstu predgovora nesmotreno poistovjećuje s cjelinom »medijskih studija« (Peruško, 2011a: 8). ${ }^{7}$

Nedostatak društvene kontekstualizacije i teorijskog uporišta. Ovakav pristup tematici možda stvara osnovu za razumijevanje stanja u vremenu u kojemu je nastao pojam »medijski sustav«, ali se ne može reći da pridonosi razumijevanju njegove današnje povećane kompleksnosti. Nadalje, s obzirom na to da se rasprava o ovom pojmu najčešće smješta na razmeđe sociologije, politologije i onoga što se široko opisuje nazivom »komunikacijske znanosti«, iznenađuje primjetna zanemarenost njegove društvene komponente, odnosno izostanak podrobnijeg objašnjavanja širega društvenog konteksta njegova nastanka i njegovih implikacija. Isto se može reći i za druge pojmove obrađene u cjelini teksta predgovora i uvodnog poglavlja zbornika.

Primjerice, autorica u uvodnom poglavlju navodi da Abercrombie i Longhurst (2007) »izjednačavaju termine mediji i masovni mediji, iako napominju da sintagma 'masovni mediji' sadrži sasvim određenu teorijsku pozadinu koja je u nastanku povezana s konceptima masovnog društva, masovne publike i masovne komunikacije« (Peruško, 2011b: 18). U nastavku teksta, međutim, propušta objasniti postavke te teorijske pozadine i pobliže analizirati pojam masovnog društva, ključan za razumijevanje teme i cjelokupnog područja u koje se rasprava smješta.

Izostanak šire društvene kontekstualizacije pedagoški je jednako problematičan i kad je riječ o prikazu razvoja teorija o masovnom komuniciranju. Ne samo u tekstu predgovora, nego i u cjelini izdanja, čitatelj/ica teško da će o karakteru i kontekstu nastanka pojedinih škola komunikacijskog istraživanja doznati više od onoga što autorica preuzima kao izravan citat iz uvoda u izbor Katza i dr. (2003: 6): »Chicago, gdje je sve počelo; Columbia, poznata po istraživanjima persuazije (nagovaranja) i gratifikacije (zadovoljenja potreba); Frankfurt, poslovičan dom kritičke škole medijskih studija; Toronto, slavan po tehnološkom determinizmu; i britanske kulturne studije koje bi možda bilo bolje nazvati birminghamskim da njihov utjecaj nije tako raširen u cijeloj Britaniji« (Peruško, 2011a: 9).

Dakako, u predgovoru ograničene duljine, pa i u ovakvom zborniku opće namjene, nije moguće potanko izložiti postavke, disciplinarni kontekst, rezultate i društvenu recepciju svih poznatijih teorija masovnog komuniciranja. No, da je predočeni izbor ipak odviše skučen i selektivan, svjesna je i sama autorica, koja već u sljedećoj rečenici kaže: »Ovdje još nedostaje barem francuski i švicarski doprinos semiotike počecima medijskih studija« (Peruško, 2011a: 9).

\footnotetext{
${ }^{7}$ Istini za volju valja reći da na završnim dvjema stranicama poglavlja s naslovom »Što su mediji?«, Peruško spominje »nove medije« i eksplicite ih diferencira od masovnih. No, riječ je samo o načelnom spominjanju postojanja te razlike i primjerima upotrebe pojedinih aplikacija: izostaje supstancijalna rasprava o naravi društvenih i kulturnih promjena povezanih sa širenjem »novih medija i tehnologija« te njihovom odnosu prema »masovnim medijima«.
} 
Popis neuvrštenih pristupa istraživanju medija mogao bi biti i znatno dulji, ${ }^{8}$ no temeljnom poteškoćom ostaje to što ni spomenute »škole« nisu prikladno objašnjene s jasno definiranoga teorijskog motrišta. Čitateljstvu koje tek ulazi u svijet medija i medijskih istraživanja potrebno je suvereno vodstvo kroz prošlost i sadašnjost područja, uz nedvosmisleno naznačivanje uporišta s kojeg se kreće u raspravu i granica terena koji ona pokriva. Dojam konfuzije koji se stvara izostane li takvo objašnjenje može zasmetati onima koji tematiku već poznaju, no u potpunih početnika/ca stvara osjećaj izgubljenosti i nedostatka oslonca.

Neuravnoteženosti u izlaganju. Poteškoća sa zbornikom Uvod u medije jest u tome što se prethodno spomenuti nedostaci njegova predgovora i uvodnog poglavlja u nastavku izlaganja građe ne ispravljaju, nego se ponavljaju, pa i produbljuju. Ovo se ponajprije odnosi na neuravnoteženosti u načinu iznošenja cjeline prikaza pojedine teme i dojam nedovršenosti pojedinih izvoda u koje se njihovi autori/ ice upuštaju. ${ }^{9}$ Može se pretpostaviti da su ovakve nesavršenosti dijelom posljedica urednički preambiciozno postavljenih zadataka, ali ni pojedinačne autore/ice ne bi bilo primjereno posve amnestirati od odgovornosti za konačni proizvod.

Nadalje, baš kao i u tekstovima predgovora i uvodnog poglavlja zbornika, golema većina spomenute i preporučene literature i u svim se njegovim ostalim poglavljima odnosi na radove hrvatskih autora/ica ili pak na radove izvorno objavljene na engleskom govornom području. Preciznije rečeno, od ukupno 302 bibliografske jedinice koje nalazimo u popisima literature uz pojedinačna poglavlja, čak se 155 (51,32\%) odnosi na radove nastale i objavljene u Hrvatskoj, 125 (41,39\%) na one s engleskog govornog područja, a samo $22(7,28 \%)$ na radove nastale $u$ drugim kulturnim kontekstima i intelektualnim tradicijama. ${ }^{10}$

${ }^{8}$ Ograničimo li polje samo na pristupe proučavanju »masovnih komunikacija«, prema klasičnom - prije više od četvrt stoljeća objavljenom - Wolfovu pregledu (Wolf, 1985), nedostaju, primjerice: početni - predempirijski i, često, popularni - odgovori unutar različitih disciplina na širenje masovnih medija, potom empirijsko-eksperimentalna istraživanja, funkcionalistička teorija masovnih medija, kulturološka teorija Edgara Morina, prijelaz s informacijskog modela komuniciranja na semiotičko-informacijski pa potom semiotičko-tekstualni, te na koncu različiti prilozi istraživanju medijske konstrukcije zbilje, kao i pomaku žarišta proučavanja sa sociologije pošiljatelja na proces stvaranja vijesti (newsmaking).

${ }^{9}$ Iznimka je u ovom pogledu vrlo korektan i tečan prikaz povijesti, sadašnjosti i očekivane budućnosti novinskih agencija koji je priredio Fjodor Polojac, a donekle i prilog o povijesti radija Marine Mučalo, koji je ipak fragmentarniji i neprimjereno pojednostavljen u pojedinim aspektima prikaza širega povijesnog konteksta.

${ }^{10}$ Pojedini spomenuti radovi poznatih autora afirmiranih u neanglofonom kulturnom kontekstu, a objavljeni u časopisima i zbornicima na engleskom jeziku, također su pribrojeni radovima nastalim u drugim kulturnim kontekstima. Također valja napomenuti da $\mathrm{u}$ izračunu nisu uzimane u obzir pojedine bibliografske jedinice iznesene u podnožnim bilješkama, a kasnije - zbog autorske i uredničke nedosljednosti - nenavedene u popisima spomenute literature na završetku pojedinačnih poglavlja. Nadalje, neke se (iste) jedinice pojavljuju u više takvih popisa. Izračun, dakle, valja shvatiti orijentacijski, kao pokušaj približne brojčane ilustracije dojma stečenog nakon čitanja cjelokupnog teksta zbornika. 
Iako je nesporno da su različiti pristupi nastali u anglofonom kulturnom krugu osobito istaknuti u povijesti proučavanja medija, ovakva jednodimenzionalnost (ili, točnije: dvodimenzionalnost) glavnih bibliografskih izvora ipak je zabrinjavajuća. Ne samo stoga što pokazuje stanovitu provincijalnost sredine u kojoj zbornik nastaje i kojoj se obraća, nego i stoga što svaki odviše jednoznačno usmjeren izbor izvora nužno smanjuje mogućnost odmaka od matice i na njemu zasnovane metateorijske refleksivnosti. ${ }^{11}$

Dok se velika zastupljenost hrvatskih autora i autorica u bibliografskim izvorima može pripisati uredničkom zahtjevu za uključivanjem u raspravu povijesti i sadašnjosti medija u Hrvatskoj, golema prevlast izvora nastalih na engleskom govornom području pri obrađivanju stanja medija »u svijetu«, čini se da ipak neovisno od bilo kakvih uredničkih zahtjeva - upućuje na općenite bibliografske preferencije u predmetnom akademskom području u nas.

Sljedeća je poteškoća s izvorima u odviše velikom osloncu na udžbeničku literaturu i radove preglednog karaktera, što navodi na zaključak o nedovoljno samostalnom vođenju rasprave o izvornim radovima i postavkama obrađivanih autora. Ovo je osobito uočljivo u jedinom poglavlju zbornika koje, uz predgovor i uvodno poglavlje, posjeduje stanovitu aspiraciju na metateorijsku refleksiju (riječ je o poglavlju naslovljenom s »Istraživanje publika«). Takva je aspiracija, međutim, u korijenu presječena ropskim slijeđenjem i kompiliranjem nedovoljno usustavljenih fragmenata udžbeničkih predložaka, uz konfuznost nepriličnu propedeutičkoj svrsi priloga i u mjeri koja u pojedinim dijelovima dovodi u pitanje njegovu izvornost. ${ }^{12}$

Dojam znanstvene nesustavnosti stvaraju i neujednačen tretman i vrednovanje pojedinih navođenih izvora, primjetni u više priloga u zborniku. U publikaciji udžbeničkog i priručničkog žanra, koja - unatoč dinamičnom razvoju svog predmeta ipak nužno aspirira na određenu trajnost, jednostavno je neprimjereno $u$ istom rangu navoditi postavke radova nastalih u akademskom kontekstu i postavke tekstova objavljenih u dnevnim novinama. Isto vrijedi i za rečenice izrečene u televizijskim emisijama te na stručnim skupovima ili predavanjima glasovitih znanstvenika i stručnjaka u pojedinim s medijima povezanim zanimanjima. ${ }^{13}$

${ }^{11} \mathrm{Uz}$ autorovu akribičnost, upravo je takva distancirana metarefleksivnost razlog iznimne kvalitete spomenutog Wolfova pregleda teorija o masovnom komuniciranju (Wolf, 1985). Kao primjer pregleda koji je profitirao od »drukčijeg pogleda« može se navesti i priručnik Mattelarta i Mattelart (1998), za razliku od Wolfova, dostupan i na engleskom jeziku.

${ }^{12}$ Nije riječ o plagijatu, jer se u stopu slijeđeni izvori svaki put uredno navode. Ipak, u izvornim, pa i preglednim radovima, doista je neuobičajeno naići na navođenje istog izvora čak 44 puta u 303 retka ili drugoga takvog izvora čak 30 puta u 160 redaka teksta. U prvom spomenutom slučaju riječ je o referiranju između 270 i 279 stranice zbornika na objašnjenja iz knjige Ine Bertrand i Petera Hughesa (2005), a u drugom o referiranju između stranice 280 i 286 na kratko priručničko poglavlje Raya Kenta (2002).

${ }^{13}$ Ilustracije radi, mogu se navesti tekstovi podnožnih bilježaka na str. 69 (»Hrvoje Krešić, 'Internet neće ubiti novine', Novi list, 28. studenog 2009, str 14.«), str. 160 (»Mark Oliver govorio je o budućnosti BBC-ja u prilogu Jasne Paro u vanjskopolitičkom magazinu $\mathrm{Pa}$ - 
U ovom kontekstu, kao pedagoški osobito neprikladan valja navesti primjer nerazlučenog i nekontekstualiziranog dovođenja u vezu općepoznatih pojmova i pristupa isključivo s hrvatskim znanstvenicima, uz to još u segmentu teksta koji slijedi intencije i argumentaciju priloga objavljenoga u dnevnim novinama. ${ }^{14} \mathrm{U}$ ovom, srećom ipak usamljenom primjeru, pokazuju se krajnje posljedice tehnike inzularnog navođenja izvora, koju na sličan način primjenjuju i brojni drugi prilozi u zborniku, ali koja je u ukupnosti građe što ju iznose ipak manje izravno uočljiva nego u ovom drastičnom slučaju.

Nažalost, što zbog selektivnog pristupa izvorima i nedostatka znanstvene postupnosti u izlaganju, što zbog nedovoljne uredničke koordinacije ukupnosti iznesene građe, čitatelji/ce koji se potrude do posljednje stranice iščitati opsežan tekst zbornika, ipak neće nigdje naići na cjelovita i u znanstvenoj literaturi utemeljena objašnjenja nekih od temeljnih pojmova u proučavanju područja.

Neobjašnjeni pojmovi. Primjerice, u zborniku nije moguće pronaći takvu definiciju pojma »novi mediji«, osobito u onim njezinim aspektima koji omogućuju povezivanje sa širim kulturnim kontekstom. Sam pojam više se puta spominje u različitim poglavljima zbornika, no posve izostaje pozivanje na već klasičnu znanstvenu definiciju Leva Manovicha (2001) ili standardnu priručničku Listera i dr. (2003).

U poglavlju s naslovom »Novi mediji i novinarstvo na internetu«, važan povezani pojam »konvergencije« obrađuje se u tehnološkom i poslovnom kontekstu, ali ne i u okviru medijske i kulturne povijesti, u koji ga smješta dosad najzapaženija publikacija na temu (Jenkins, 2006). Na isti način, izostaje i spominjanje drugih ponajprije medijski i kulturno uokvirenih pojmova koji bi novinarstvo u novom kontekstu pomogli povezati s logikom digitalnih interaktivnih platformi, poput primjerice također već klasične »remedijacije« (Bolter i Grusin, 1999).

Kad je pak riječ o pojmu »masovni mediji«, unatoč ranije spomenutom nedostatku objašnjenja povezanog pojma »masovno društvo«, zbornik ipak predočava znatno više elemenata na temelju kojih se mogu donijeti zaključci o njihovu karak-

ralele, emitiranom 14. veljače 2010. na HTV1.«), str. 206 (»N. Negroponte u Zagrebu, 29. veljače 2008.«) i str. 243 (»Michel Grégoire, istaknuti medijski stručnjak iz Belgije, u predavanju na 12. Nacionalnom festivalu oglašavanja FESTO 2005.«). S obzirom na prethodne primjere, ne čudi ni to da se Weberova definicija moći, u podnožnoj bilješci na str. 241, smješta u povijesni kontekst na sljedeći način: »Max Weber, njemački sociolog. Iskaz o problemima političkog predstavlja njegovo izlaganje Politik als Beruf (Politika kao poziv), održano pred münchenskim slobodnim studentima revolucionarne 1919. godine«.

${ }^{14}$ Riječ je o pojmu »medijska ekologija« i pristupu »medijske pedagogije«. Oni se spominju u četrnaest redaka dugom izvodu na str. 79 poglavlja zbornika posvećenog novinama. U tom se izvodu, nastalom na temelju članka objavljenog u dnevnom listu, spomenuti pojam dovodi u vezu s imenom jednoga hrvatskog znanstvenika, a pristup s imenom jedne hrvatske znanstvenice. Ni u izvodu, ali ni u cjelini članka, nema ni spomena povijesnog doprinosa Neila Postmana definiranju pojma »medijska ekologija« u obrazovnom kontekstu, niti postavki današnje interdisciplinarne znanstvene udruge koja okuplja istraživače/ ice u području (The Media Ecology Association). Aspekti razgranate djelatnosti međunarodno poznate njemačke medijske pedagogije također ostaju nespomenutima u izvodu. 
teru i načinu djelovanja. Unatoč tomu, čitatelji/ce će nužno morati uložiti stanovit napor u prebiranje ponuđenoga, jer definicija nije prezentirana tečno u jedinstvenom objašnjenju, a neke su od iznesenih naznaka međusobno u sukobu.

U uvodnom se poglavlju tako prenosi Thompsonovo (1997) skretanje pozornosti »na čestu zabludu da je u masovnoj komunikaciji nužno riječ o velikim, masovnim publikama. To nije uvjet jer knjigu ili nosač zvuka koji su prodani u malom broju primjeraka i dalje ubrajamo u masovne medije zbog strukturalnih osobina njihove proizvodnje i distribucije i činjenice da su bili ponuđeni masovnoj publici« (Peruško, 2011b: 19). No, naslov sljedećeg poglavlja (»Knjiga u Hrvatskoj - masovni medij?«) očito povezuje brojnost prodanih primjeraka s karakterizacijom medijskog proizvoda, upućujući tako na posve različito shvaćanje i unoseći nepotrebnu zabunu u ionako zahtjevan posao početničkog snalaženja u području.

Potreba uredničke koordinacije. Ovakvi primjeri pokazuju da bi izdanje bilo dobilo na vrijednosti uz više uredničke koordinacije, pa i redaktorskog zadiranja u sadržaj pojedinih poglavlja. ${ }^{15}$ Proklamirana koncepcija prema kojoj su autori/ce preuzeli odgovornost za pojedine teme i poglavlja urodila je, naime, ne samo prezentacijskim neuravnoteženostima, nego i razlikama u samoj prirodi pristupa materijalu. Takve pak razlike čitatelja ili čitateljicu kojima su namijenjene ostavljaju bez spoznaja u pojedinim područjima važnim za postizanje temeljnog cilja izdanja, a to je pružanje već spomenutoga »prv[og] cjelovit[og] uvid[a] u razumijevanje medija« (Peruško, 2011a: 7).

Kako će se, primjerice, steći takav cjeloviti uvid u - kako kaže njegov naslov - »Filmski medij«, kad je to poglavlje zbornika u potpunosti posvećeno prikazivanju povijesti filma na tlu Hrvatske? S druge strane, poglavlje »Televizija« pokušalo je - s promjenjivim uspjehom - odgovoriti na doista sve uredničke zahtjeve, pa tako na prostoru manjem od jedne stranice u knjizi pokušava sažeti i kompleksnu građu o prostornim i vremenskim okvirima filmskog i televizijskog prikaza stvarnosti (po Peterliću).

Uredničke intervencije bile su osobito potrebne kad je riječ o primjerima selektivnog ili faktografski nepotvrđenog prikazivanja povijesti pojedinog medija ili medijske profesionalne prakse u Hrvatskoj. ${ }^{16}$ Također, većina prikaza njihova

\footnotetext{
${ }^{15}$ Valja napomenuti da se potreba redaktorske obrade ne odnosi samo na sadržaj pojedinih poglavlja, nego i na njihovu jezično-stilsku komponentu. U tekstu zbornika primjećuje se niz stilskih neujednačenosti, među kojima je - s obzirom na njegovu udžbeničku namjenu - osobito upitna upotreba jezičnih registara neprimjerenih akademskom diskursu. Isto tako, nisu otklonjene nedosljednosti i pogreške pri navođenju bibliografskih jedinica, kao ni slovne tiskarske pogreške, pa ni pojedine gramatičke i pravopisne pogreške.

${ }^{16} \mathrm{~S}$ uredničkog motrišta, nedopustivo je da se u poglavlju o novinama iz ovlašnog prikaza povijesti novinstva u Hrvatskoj posve isključe sedamdesete godine dvadesetog stoljeća, značenje magazina Start ili uloga tadašnjega omladinskog tiska, a u tranzicijskom razdoblju izostavi bilo kakav spomen na ulogu i mjesto tjednika Feral Tribune. Upitnih pojednostavljenja tematike ima i u poglavlju o odnosima s javnošću. Ondje se nedovoljno diferencirano pristupa primjerima praksi koje su obavljale njihovu ulogu u socijalističkom razdoblju.
} 
razvoja znatno bi se unaprijedila uključivanjem makar elementarnih referenci na širi društveni i kulturni kontekst, izrečenih s motrišta i uz upotrebu standardnog nazivlja društvenih znanosti.

Konačno, uz bolju uredničku koordinaciju građe, vjerojatno se ne bi dogodilo da kao jedinica za zasebnu obradu u poglavlju bude odabrana »povijest stripa«, a iz zbornika posve izostane medij fotografije, ključan ne samo zbog svoje uloge u razvoju medijske teorije, nego i definiranju postavki brojnih kulturnih praksi i odnosa, između ostaloga i u novinarstvu i drugim profesionalnim praksama koje su zastupljene u zborniku.

Sljedeći koraci. U zaključku valja reći da - unatoč brojnim razmotrenim nedostacima - zbornik Uvod u medije ipak ispunjava stanovitu svrhu u akademskom prostoru u kojem je zamišljena njegova upotreba. Kao prvi pokušaj svoje vrste, on je - u najmanju ruku - ocrtao područje u kojem se rasprava o budućim potrebama i sljedećim koracima može odvijati. Istraživanja različitih aspekata medijskog prostora vrlo su aktualna pa se potražnja za ovim i njemu sličnim priručnicima zasigurno neće smanjiti. Svaki sljedeći sličan napor procjenjivat će se upravo u odnosu na namjere i postignuća ovoga ambicioznog ali u konačnici nedovoljno ostvarenog prvog pokušaja. To također vrijedi i za eventualno drugo i daljnja izdanja ovog zbornika, čiju bi građu - u svrhu veće pedagoške uspješnosti i znanstvene ovjerenosti - valjalo nadopuniti, a u pojedinim dijelovima i posve izmijeniti.

\section{LITERATURA}

Abercrombie, Nicholas i Longhurst, Brian (2007). The Dictionary of Media Studies. London: Penguin.

Balle, Francis (2003). Médias et sociétés. 11e éd. Paris: Montchrestien.

Balle, Francis (2004). Les médias. Paris: Presses Universitaires de France.

Baran, Stanley J. (2002). Introduction to Mass Communication: Media Literacy and Culture. 2nd ed. Boston: McGraw-Hill.

Bertrand, Ina i Hughes, Peter (2005). Media Research Methods: Audiences, Institutions, Texts. Basingstoke: Palgrave Macmillan.

Bolter, Jay David i Grusin, Richard (1999). Remediation: Understanding New Media. Cambridge, Mass. i London: The MIT Press.

Bolz, Norbert (2007). Das ABC der Medien. München i Paderborn: Wilhem Fink Verlag.

Briggs, Asa i Burke, Peter (2005). A Social History of the Media: From Gutenberg to the Internet. 2nd. ed. Cambridge: Polity.

ESA RN 18 (2010). »Europe and the Media: New Developments in Social Theory and Research« [Call for Papers, Mid-term Conference, European Sociological Association, Research Network 18], http://www.europeansociology.org/index. php?option $=$ com_content\&task=view\&id=36\&Itemid $=29$ (10. 08. 2011.).

Giddens, Anthony (2007). Sociologija. Zagreb: Globus.

Jenkins, Henry (2006). Convergence Culture: Where Old and New Media Collide. New York: New York University Press. 
Katz, Elihu, Peters, John Durham, Liebes, Tamar i Orloff, Avril (ur.) (2003). Canonic Texts in Media Research. Are There Any? Should There Be? How about These? Cambridge: Polity.

Kent, Ray (2002). »Audience Research: Administrative Research of Audiences«, u: Adam Briggs i Paul Cobley (ur.). The Media: An Introduction. 2nd ed. Harlow: Longman, str. 245-258.

Lazar, Judith (1992). La science de la communication. Paris: Presses Universitaires de France.

Le Coadic, Yves-François (1994). La science de l'information. Paris: Presses Universitaires de France.

Lister, Martin, Dovey, Jon, Giddings, Seth, Grant, Iain i Kelly, Kieran (2003). New Media: A Critical Introduction. London i New York: Routledge.

Manovich, Lev (2001). The Language of New Media. Cambridge, Mass. i London: The MIT Press.

Mattelart, Armand i Mattelart, Michèle (1998). Theories of Communication: A Short Introduction. London: Sage.

Mulder, Arjen (2004). Understanding Media Theory: Language, Image, Sound, Behavior. Rotterdam: V2_Publishing i NAi Publishers.

Peterlić, Ante (2001). Osnove teorije filma. 4. izd. Zagreb: Hrvatska sveučilišna naklada.

Peruško, Zrinjka (2011a). »Predgovor. O medijima i medijskim studijama«, u: Zrinjka Peruško (ur.). Uvod u medije. Zagreb: Naklada Jesenski i Turk i Hrvatsko sociološko društvo, str. 7-13.

Peruško, Zrinjka (2011b). »Što su mediji?«, u: Zrinjka Peruško (ur.). Uvod u medije. Zagreb: Naklada Jesenski i Turk i Hrvatsko sociološko društvo, str. 15-40.

Silverstone, Roger (2005). »The Sociology of Mediation and Communication«, u: Craig Calhoun, Chris Rojek i Bryan Turner (ur.). The Sage Handbook of Sociology. London: Sage, str. 188-207.

Solar, Milivoj (2005). Teorija književnosti. 20. izd. Zagreb: Školska knjiga.

Sorice, Michele (2005). I media. La prospettiva sociologica. Roma: Carocci.

Sorice, Michele (2009). Sociologia dei mass media. Roma: Carocci.

Thompson, John B. (1997). »Mass Communication, Symbolic Goods and Media Products«, u: Anthony Giddens (ur.). Sociology: Introductory Readings. Cambridge: Polity, str. 129-133.

Wolf, Mauro (1985). Teorie delle comunicazioni di massa. Milano: Bompiani. 